\title{
Wetlands and Waterfowl*
}

\section{by H. Albert Hochbaum, Director of the Delta Waterfowl Research Station}

The Delta Marsh, in Manitoba, is a great and famous place, renowned for its waterfowl and, of course, for its hunting. I can never forget my first visit there. Travelling up from Madison, Wisconsin, I drove all day across the prairies of Minnescita. Here and there along the way were sloughs and potholes (many of them now gone), each holding a few ducksShovelers, Blue-winged Teal, Mallards and Pintails with now and again a pair of Redheads or Canvasback. As the sight of ducks excited me, I kept saying to myself: "This is nothing; just wait until I arrive on the Delta Marsh. There'll be vast numbers of waterfowl, huge flocks of them and great clouds more will rise as I round each ibend, countless thousands of ducks for me to behold in the heart of their June breeding marsh."

There was then, in 1938, still little understanding about the spring populations of the breeding grounds. My first view of the great marsh was thus a tremendous disappointment. To be sure, there were many birdsFranklin's Gulls by the thousand, Western Grebes, Eared Grebes, Forster's Terns and Black Terns in wonderful abundance. But the ducks were only in scattered pairs and singles, and occasionally small flocks. Wherever I went there were ducks, but nowhere many. Of course, Seton had once expressed a similar disappointment and I should have learned of this from his writings. In his travels over the Canadian prairies he asked the settlers "Where do the ducks breed?" And always the reply was "North." No matter how far north he went, the reply was still "North." "Oh yes," the settler would say, "A few ducks nest around here, but most of them continue on." We often discussed this point at Delta years later and Bob Smith, who made some of the first aerial waterfowl surveys of the Arctic, was greatly amused when he reached the shore of the Arctic Ocean. "Yes sir," the people said, "there are some ducks here; but most of them fly north to breed."

Ducks, of course, are not like gulls or terns. However gregarious in summer, fall and winter, the pairs must separate each to itself when it comes time to nest. Nowhere are there dense populations of pairs. So we learned that however important their function in summer and fall-as gathering and moulting places-the great stretches of marsh water, such as the Delta Marsh, play only a minor role as breeding range. For example the vast Delta Marsh with its seemingly limitless horizons holds fewer breeding ducks per square mile than the Minnesota pothole country. And this pothole range, where one is seldom beyond sight of ducks or farmsteads, covers thousands of square miles while the famous marsh itself holds less than sixty sections. It is much the same in Saskatchewan and North Dakota as elsewhere on the nesting grounds. Farmland pothole country accommodates more of our breeding game waterfowl than the huge marshes. In North Dakota, which has more breeding ground refuges than any other state in the U.S.A., figures presented by the U.S. Fish and Wildlife Service indicate that less than two per cent of the state's waterfowl nest on public sanctuaries. The rest are on small waters, mainly on private land.

We thus understand the importance of private land and small waters in the overall production of waterfowl. And when these areas fail, as in the present drought, there must also be a failure of many breeding attempts. Until recently we believed that when dry years came the waterfowl would shift to use the large stable marshes: the refuge areas and "duck factories" where water levels were held under permanent control. But this current dry spell has shown that this is not so. The refuges can hold only so many breeding pairs per square mile. Every section, every township, has its saturation point. When this is reached, the area cannot accommo- 
date more productive pairs; indeed, there is some evidence that increase beyond a certain density will actually inhibit nesting and reduce local nesting success. In June, 1959, some managers of refuges in Minnesota and North Dakota were heartened by an influx of many pairs of Redheads, Mallards and other kinds, while similar gatherings built up on the larger marshes of Manitoba. But by early July it became apparent that these birds, displaced from some dried-out range, had not arrived to nest. They simply came to pass the time of day until their summer molt; then the gatherings travelled south without having experienced successful reproduction. This reduced nesting was evidenced in the fall bag tallies of 1959 which showed that in the Mallard and some other important prairie-breeding game species, hunters were killing more adults than young, harvesting the "capital stock" in a lean year when the crop of new birds .was restricted.

Some of these ducks had tried to nest on their old haunts, but failed because of an early dry-out. Others had gone to new places, after they had found their old homes dry; but because of the delayed start, there were few renesting attempts. Still others tried to nest in thin vegetation around the drying water areas, but predator efficiency was greatly increased in the sub-standard cover. And some did noit even attempt to nest, their breeding activity inhibited by some environmental factors related to the drought. The long and short of the season was a year of low success because of the dryingout of small waters on private land.

This is a very important point for us to understand, because drainage threatens ito permanently remove mcst or all of these small nesting marshes from the agricultural range. And where they are gone forever, the rise and fall of waterfowl will not follow the wet and dry cycles; reductions will be permanent.

At one time the slough and pothole country reached far south of Saskatchewan into Iowa and southern Minnesota. This spring I spent two weeks in parts of these states which less than fifty years ago held a tremendously rich wildlife population. In the early pant of this century, that country was wilder than southern Saskat- chewan is now, the wildlife more abundant and varied because the land is richer, the climate more temperate. Old-timers told me of the abundance of Pinnated Grouse in that land where Prairie Chicken no longer live -buit mostly the stories were of the ducks and geese that used to breed there, and of the unbelievable numbers that passed through spring and fall. Heron Lake, in Minnesota, was then known as the "Chesapeake of the west" because of the large number of Canvasback there; and when they took off from Heron Lake the roar of wings could be heard several miles inland. Small marshes were in view at every glance, rich in waterfowl and other marsh life. This region was then a major part of the breeding range of ducks.

The country was almost birdless when I called there this spring; I travelled miles before seeing a Meadowlark. The sloughs were gone, all but a few, the lakes with ugly, shrunken shorelines; the grassy meadows had all but vanished. Water had left the country by way of ditch and drainage tile. Under the influence of heavy farm subsidy, land has become so valuable, that no person there feels he can truly afford to have a little bulirush and a span of water for a pair of teal on his property. It interested me that even those who condemned drainage and were saddened by the loss of breeding waterfowl had themselves removed the marshes from their own farms. When I mentioned this the answer would be: "I drained because I had to; I couldn't afford to do otherwise." This drainage was done with the aid of public funds in a land where one is seldom beyond sight of storage bins holding grain that cannot be sold. Here on these beautiful prairies the people are trading their small waters at public expense, for agricultural land to raise crops that have no market.

I also visited Mahnomen County in Central Minnesota (Mahnomen is the Indian word for Wild Rice); and there too the potholes are being drained. This is farther north and the job is only about half done. Here I saw the Federal Soil Bank, a program whereby farmers are paid to leave good land inactive. Rich farmland is taken out of production to reduce the harvest. But in this same county, potholes are also being 
drained, again at public expense, to bring these wetlands into the realm of agriculture. In Mahnomen County and farther south around Heron Lake, many local people deplored the situation; they were saddened by the loss of their wetlands and their waterfowl. But everywhere I went I was aware of their one great consolation: the marshlands in Canada were unlimited, forever a place to go for recreation, forever a source of waterfowl when the agricultural counties of Minnesota and the Dakotas are drained. I suspect that many of these people would be sobered if they could only read the very fine report by Herb Moulding on the progress of drainage in Saskatchewan.

Drainage, of course, is not the ondy threat to waterfowl. Despite the fact that Mahnomen County, Minnesota, now has only half its marshes, the remaining sloughs and potholes are losing their breeding ducks with the reduction most severe in the Canvasback and Redhead. Surveys by the Minnesota State Conservation Department have shown a steady decrease in the numbers of breeding waterfowl in the remaining marshes even though these places have not been affected by drought and remain fine waterfowl breeding habitat. On the Lower Souris Refuge, in North Dakota, Redheads comprised about twenty-five per cent of the breeding population only a few years ago; now this species makes up hardly five per cent of local breeders. In Manitoba, the Mallard, which has always been one of the commonest nesting species, has declined on range that is good Mallard breeding habitat. In the early 1950's at Delta one could hardly spend a morning's casual walk without finding four or five iMallard nests. Now several mornings of intensive search may pass before a nest is found. Thus, in some impontant areas where habitat remains good, ducks are not present in sufficient numbers to use all the available nesting range. The implication is that waterfowl may be suffering from some other pressures besides drought and drainage.

It is important for us, as a group of scientists and naturalists, to consider the importance of managing waterfowl on a biological basis. At present we control the waterfowl re- sources in two ways: firstly by the very resitricted protection of breeding habitat; and secondly with the regulations governing the harvest by guns. Certainly in the control of the harvesit there is much room for the application of information we now have in hand regarding the habits and life histories of the various species. In upland game, province by province, state by state there is a strong sense of responsibility to husband local supplies. Thus when new observations and discoveries are presented regarding the life habits and requirements of native game species, these quickly influence the plan for shooting. Native game is taken only when it is prime and ready, gunning limited to those years when there is a harvestable surplus, schedules and areas of shooting arranged with the welfare of the game in mind.

How different it is with waterfowl! Seldom is there evidence of local responsibility; and certainly the open seasons are at the convenience of the hunter at all latitudes, arranged with little thought to the special needs of one or another of the many species of waterfowl. The general attitude toward waterfowl was expressed recently in Minneapolis by a very intelligent and successful businessman. "I know duck hunting isn't what it used to be," he said; "But what are we to do? If we don't get our share in Minnesota they'll get them in Texas anyway." Surely, region by region, waterfowl are managed on a political rather than on a biological basis so that every man has his chance to harvest his birds before the next men on down the line take their share.

If we are to keep waterfowl as a harvestable resource we must manage the kill by plans based more solidly on our understanding of the biology of these birds. This must be done in an international manner with every region aware of its local responsibilities to this resource. As an example, let me cite our own management of the Canvasback and the Readhead. Only this morning (October 22) at Delta I saw a wild Redhead adult female with her wing feathers less than half grown. Throughout September in the southern parts of the prairie Provinces and northern tier of States there were many young diving ducks 
and their mothers which were not yet able to fly. And yet the season on their breeding and molting marshes begins before the end of summer. This places these species under a grave and certainly a most unsportsmanlike hazard, albeit they are this year under some plan of special protection. We manage Canvasbacks and Redheiads as if they had the same habits and were in the same abundance as Mallards and Pintails, but until we recognize the differences between these two kinds and arrange the time and the place of the kill accordingly - as is already routine with the various kinds of big game and upland game - the diving ducks will continue to lose ground.

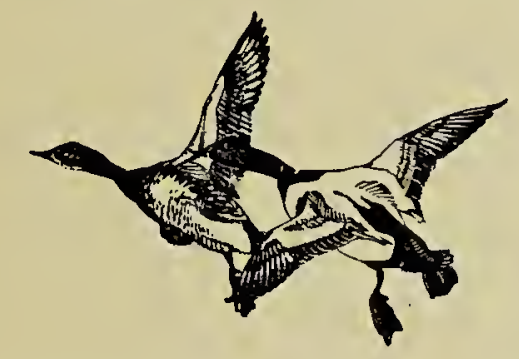

Wildlife administrators should be wise enough to look at such species management from another angle. We have been managing the Mallard and Pintail as if these were of the same habits and numbers as Canvasback and Redhead. If we can protect diving ducks on their breeding and molting marshes in late summer and early autumn, there is no reason why Mallards and Pintiails should not be harvested on agricultural fields early when their numbers warrant such advanced gunning. Such regional control is now routine with big game and upland game; it must come about eventually in waterfowl management.

Other regions are being equally selfish of waterfowl living under local responsibility for only part of the year. The method of harvesting Canada Geese in the middle-western United States is growing to the proportions of a national shame. Canada Geese, hatched and reared in ranges far beyond these mid-western staites, are enticed, during their fall migration, to state and federal refuges by strict protection and careful feeding. Then, when several years of sanctuary and fine food have attracted thousands of Canadas to such a haven, the wildlife administrators surround the refuge with state-built shooting blinds and pits. Behind this government ring of blinds, sometimes as far as twenty miles back from the refuge, private enterprise sets up a zone of commercial shooting grounds. The season is then opened on the unsuspecting geese and when the food in the refuge is exhausted, the birds must daily run the bloody gauntlet to nourish themselves. On these state shooting areas the hunter often has no other hunting activity than to hold his gun and pull the trigger. The blind is ready-made; he is directed by reflecting signs or, in some states, driven to the place of public slaughter in a state-owned vehicle. There is usually a barrier line between the public shooting range and the refuge beyond which no hunter must trespass. Even if his goose drops, he must not cross the line to pick it up or to put it to its merciful end. Behind one such barrier on a Missouri public shooting ground, investigators one year picked up more than 500 dead or crippled geese at the close of the season. The Milwaukee Journal for October 18, 1960, referred to such gunning on the Horicon Waterfowl Refuge as "a circus, a carnival, a killing resembling, if anything, a Roman arena." Biologists in some of these states are now thinking in terms of re-establishing a more natural dispersal of geese, buit a trend of local and selfish use has been established and the misfortune of these public goose baiting pits will not be corrected on short order.

Not only should the regulations for waterfowl be based upon sound biology, and an awareness of local responsibility, but the game laws must be wise and easily enforced. The late T. Gilbert Pearson, of the National Association of Audubon Societies, urged that poorly planned, unenforceable waterfowl regulations could not help the ducks and geese, but, instead, had a tendency to induce disrespect for all game laws on the part of the hunter. Presently in both the United States and Canada there is the attempt to protect the Canvasback and Redhead by special restrictions on these species while at the same time hunters are allowed to kill other kinds of ducks on the same marshes where these protected diving ducks gather. Since very few hunters can identify Canvasback and Red- 
head in drab juvenile plumage, especially the half-light of dawn and dusk, the law is broken many times before the hunter learns of his mistakes. Moreover, it has developed that some game officers charged with enforcing inis law are not always sure themselves of the identity of these two kinds when seen in the gunners' bags; hence the rule protecting Redheads and Canvasback cannot be enforced with viger. Bag tallies show these two diving ducks still high on the order of kill on some of the marshes they use so heavily in September and early October. Often, when a hunter has killed his second or third "mistake" bird without learning how to correct his error, his illegal bag is tossed into the reeds or given to friends to circumvent the law. Rather than simply asking hunters not to shoot birds which neither they nor the enforcement officers can always distinguish from legal game under field conditions (or in juvenile plumage), a wiser plan might be to protect the special marshes in Canada and the United States where such species gather. On northern waters this might not mean permanent closure of such areas but simply a delay in the opening date until the time in October when the main body of adult females and juveniles of Redhead and Canvasback have moved on. Protection of the marshes themselves establishes an enforceable pattern under which these vulnerable species might thrive. Marco Polo, writing of the game laws of Kublai, "The Great Khan" (A.D. 1259-1294), noted, in regard to the Khan's rule against hunting between March and October, that "as the breach of this order is attended with punishment, game of every description increases prodigiously."

What can we do as a society of naturalists to protect our wetlands and their waterfowl in the face of expanding agriculture and an enlarging population? Unlike the people of Iowa and Minnesota, we cannot rely on an unlimited range to the north of us, for in the prairies of Canada we now live in the heart of the breeding grounds for our game waterfowl. What is our place as a society in wetland management, waterfowl management? A group of this kind is more important than any of us realize because we are a gathering of private citizens interested in our environment. I understand from Mr. Moulding's report that in Saskatchewan the drainage of small waters on private land goes ahead with at least fifty per cent financial assistance from the government. This is a higher rate of subsidy than applies in Minnesota or the Dakotas. It means that you and I are paying to have the sloughs drained. We thus shoulder not only an important part of the cost but a considerable responsibility. The potholes are being drained with our money, by our consent, and if we consider any part of this drainage program unwise, if we dislike the idea of removing the cattail and bulrush, the Gadwalls and Canvasback from the heritage we leave to our descendants, then it is time for us to look into the situation with care and speak with unity. Public opinion establishes public policy and the members of this Society can have a great influence on the trends in drainage.

This Society might also have a strong influence on the pattern of waterfowl management, not only here in Saskatchewan but elsewhere. The Saskatchewan Natural History Society, through its organ, The Blue Jay, has cultured a following and establishea an influence well beyond the borders of this Province. I urge your members to study waterfowl and game birds-surely investigations into the life history and ecology of these kinds is not to be limited to biologists in public office. Add the information you gain on waterfowl to our total understanding while at the same time you become versed yourselves on the work others are doing and the problems that are being studied relative to the welfare of ducks and geese. It is our responsibility to think and act and work as individual citizens and as a Society. It is essential that we learn as much as possible about wetlands, that we exert, on the basis of sound understanding, as much influence as we can toward the protection of the native waterfowl environment. It is vital that we ourselves help gather information toward the development of waterfowl regulations based on a knowledge of the habits and special requirements of the birds themselves, species by species, region by region. 